\title{
Molecular Identification of Microbial Communities in the Methane Production from Vinasse: A Review
}

\author{
Luis A. Ordaz-Díaz and Ana M. Bailón-Salas *
}

Sugars, starches, and cellulose materials are used for ethanol production. When producing a liter of alcohol, 10 to 15 liters of liquid waste are generated. This waste is called vinasse, and it generates negative impacts on the environment. The process of storing and disposing vinasse in soils generates emissions to the atmosphere, mainly methane. Anaerobic treatment allows for the capture and generation of more biogas, therefore allowing mitigation of the environmental impacts. The microbial diversity present in the anaerobic digestion (AD) of vinasse is strongly related to the efficiency and quality of methane production. The gene 16s rDNAbased molecular techniques have been the most commonly used techniques for monitoring microbial communities present in the digesters. However, the identification is not enough. Rather, it is necessary to know the metagenomic functionality in this type of habitat. This review provides a comprehensive overview of methods to identify the microorganisms in the anaerobic digestion of vinasse. In addition, microbial community identification in vinasse reactors and their relationship with methane production are reviewed.

Keywords: Biogas; Vinasse; Anaerobic biological treatment; Wastewater; Digester

Contact information: Ingeniería en Tecnología Ambiental, Universidad Politécnica de Durango, Carr. Dgo-Mex Km 9.5, Col. Dolores Hidalgo, 34300, Durango, Dgo., México;

*Corresponding author: bailon_anna@hotmail.com

\section{INTRODUCTION}

There are three main types of raw materials used in the manufacture of ethanol via fermentation: sugars, starches, and cellulose materials (Lin and Tanaka 2006). The distillation stage generates up to 10 to $15 \mathrm{~L}$ liquid waste per liter of ethanol (García et al. 1997; Moraes et al. 2015). This acidic waste liquid is very aggressive to the environment due to its high content of toxic and recalcitrant organic matter (Robles-González et al. 2012). Vinasse has the following characteristics: a $\mathrm{pH}$ between 3.9 to 5.1, a chemical demand of oxygen (COD) in the range of 50,000 to $95,000 \mathrm{mgL}^{-1}$, a high concentration of total solids (TS) $\left(79,000\right.$ to $\left.37,500 \mathrm{mg} \mathrm{L}^{-1}\right)$, and a high level of volatile solids (VS) $(79,000$ to $82,222 \mathrm{mgL}^{-1}$ ) (Moran-Salazar et al. 2016).

Vinasses are effluents that are difficult to treat; soil fertilization has been a common technique for final disposal (Moran-Salazar et al. 2016). During such disposal, the waste is not actually treated. It has been reported that this disposition, storage, and fertilization generates $\mathrm{CO}_{2}$ and methane emissions (do Carmo et al. 2012; de Oliveira et al. 2013; Moraes et al. 2017), as well as negative environmental impacts (Cruz et al. 1991). In addition, methane is the second most important greenhouse gas induced by man after carbon dioxide (Saunois et al. 2016).

The anaerobic digestion (AD) allows for the capture and generation of biogas. The 
anaerobic treatment of the vinasse also generates a low production of sludge and can be used to reduce the contamination while producing biogas, which can be used as a source of renewable energy (Belhadj et al. 2013; Fuess et al. 2018; Volpini et al. 2018). In the anaerobic treatment of vinasse, the production of biogas is between 400 and $600 \mathrm{~L}$ per $\mathrm{kg}$ of COD, which is eliminated with a methane content of 60 to $70 \%$ (Moletta 2005). The advantage of methane is that it is odorless, colorless, and non-poisonous. Furthermore, it is easily separated from the liquid phase, which can contribute to the reduction of the process costs (Marty et al. 2001; Lu et al. 2009). Due to the presence of mezcal, vinasses have similar physiochemical characteristics with tequila, sugarcane, and beet vinasse (MoranSalazar et al. 2016). These could also be used for the generation of renewable energy and reduce the polluting potential (Leme and Seabra 2017).

The efficiency and quality of the process depends on the composition and activity of the microbial community that is present (Christy et al. 2014; Bailón-Salas et al. 2017a), i.e., temperature and $\mathrm{pH}$ (Basu 2010). So, the lack of knowledge of the microbial communities present in $\mathrm{AD}$ of vinasse limits the capacity to maximize the methane production. In $\mathrm{AD}$ of vinasse, changes in the structure of microbial communities have been rarely studied (Jiménez et al. 2018). In the next sections, molecular techniques for the microorganism identification in diverse vinasses are summarized. The National Center for Biotechnology Information (NCBI) database is an important resource relevant to biotechnology and has been used in this review. Besides, a search about microorganisms identified in several studies was made. The methane yield also depends on using varied inoculum sources in varied vinasse types.

\section{Vinasse Types of and Methane Yield}

The vinasses composition varies depending on the biomass used for the ethanol production (España-Gamboa et al. 2011). Many feedstocks have been used for alcohol production, and these confer unique characteristics to each vinasse generated. The feedstocks include sugar crops (sugarcane, sugar beet, molasses, and sweet sorghum), starch crops (corn, wheat, rice, cassava, and barley), cellulosic material (harvesting crop residues, bagasse, and wood), fruit sources and Agavaceae family plant. Tables 1 to 4 detail physicochemical properties and composition of vinasses.

The distillation of sugar crops for the production of alcohol generates an effluent with a high organic matter (COD 109,700 to 57,600 $\mathrm{mg} \mathrm{L}^{-1}$ ) (Table 1).

Sugarcane vinasse is a liquid produced in the unit of rectification and distillation in bioethanol production (Parsaee et al. 2019). Some of the main parameters of sugarcane vinasse characterization are given in Table 1. Low $\mathrm{pH}$ (3.34), COD greater than 58,000 $\mathrm{mg} \mathrm{L}^{-1}$, and a BOD of $23,182 \mathrm{mg} \mathrm{L}^{-1}$ were reported.

The waste from solid-state fermentation of sorghum, corn and/or wheat is called solid vinasse (Wang et al. 2010; Ao et al. 2019). The shown value of $\mathrm{pH}$ (4.36) (Ao et al. 2019) was higher compared to sugarcane vinasse.

The most important source of starch for bioethanol is cassava. This is due to its abundance and low cost (Zhang et al. 2016). The cassava vinasses characterization is shown in the Table 2. The $\mathrm{pH}$ near 4 , COD, BOD, suspended solids, total nitrogen, and total phosphorus of up to 70,000, 35,000, 45000, 900 and $400 \mathrm{mg} \mathrm{L}^{-1}$, respectively, was reported (Luo et al. 2009). Rice wine vinasse also have low pH (3.8) (El-Zaiat et al. 2019) and lower concentrations of organic material (Table 2). 
Table 1. Characteristics of Vinasse from Sugar Crops

\begin{tabular}{|c|c|c|c|}
\hline Vinasse type & Parameter & Value & Reference \\
\hline \multirow{19}{*}{ Sugarcane } & $\mathrm{pH}$ & 3.3 & \multirow{8}{*}{ Santos et al. 2019} \\
\hline & $\begin{array}{l}\text { Chemical oxygen } \\
\text { demand }\end{array}$ & 58,533 & \\
\hline & $\begin{array}{l}\text { Biochemical oxygen } \\
\text { demand }\end{array}$ & 23,182 & \\
\hline & Butyric acid & 468 & \\
\hline & Lactic acid & 4,200 & \\
\hline & Ethanol & 15,848 & \\
\hline & Methanol & 594 & \\
\hline & Phenols & 1,706 & \\
\hline & Volatile suspended solid & 5,553 & \multirow{5}{*}{ Fuess et al. 2019} \\
\hline & Acetic acid & 1,722 & \\
\hline & Propionic acid & 127 & \\
\hline & Total carbohydrates & 7,275 & \\
\hline & Glycerol & 3,914 & \\
\hline & Sulfate & 2,993 & Correia et al. 2017 \\
\hline & $\mathrm{pH}$ & 4 & \multirow{5}{*}{ Moraes et al. 2015} \\
\hline & $\begin{array}{l}\text { Chemical oxygen } \\
\text { demand }\end{array}$ & 109,700 & \\
\hline & $\begin{array}{l}\text { Biochemical oxygen } \\
\text { demand }\end{array}$ & 87,700 & \\
\hline & Phenols & 12.4 & \\
\hline & Total solids & 5.8 & \\
\hline \multirow{3}{*}{ Sugar beet } & $\mathrm{pH}$ & 5.1 & \multirow{3}{*}{ Robertiello 1982} \\
\hline & $\begin{array}{l}\text { Biochemical oxygen } \\
\text { demand }\end{array}$ & 78,300 & \\
\hline & $\begin{array}{l}\text { Chemical oxygen } \\
\text { demand }\end{array}$ & 81,200 & \\
\hline \multirow{5}{*}{ Cane molasses } & $\begin{array}{l}\text { Chemical oxygen } \\
\text { demand }\end{array}$ & 57,600 & \multirow{5}{*}{ Bories et al. 1988} \\
\hline & Acetic acid & 616 & \\
\hline & Propionic acid & 90 & \\
\hline & Butyric acid & 290 & \\
\hline & Sulfate & 3,820 & \\
\hline
\end{tabular}

All values, except $\mathrm{pH}$ are expressed in $\mathrm{mg} \mathrm{L}^{-1}$.

Many cellulosic materials have been used in ethanol production (Lu-Chau et al. 2019). These cellulosic materials include sugarcane bagasse (Liu et al. 2015; Joppert et al. 2017), agave bagasse (Aguilar et al. 2018), newspaper (Wu et al. 2014), and coffee husks (Gouvea et al. 2009), etc. However there are few studies on physicochemical characteristics of the cellulosic vinasses. A study about the production of $2 \mathrm{G}$ ethanol from sugarcane bagasse reported COD values of $38,800 \mathrm{mg} \mathrm{L}^{-1}$ in the vinasse (Tian et al. 2013). Chemical characterization of cotton vinasse gave the following results: $\mathrm{pH} 4.7$, nitrate 350 $\mathrm{mg} \mathrm{L}^{-1}$, and ammonium $90 \mathrm{mg} \mathrm{L}^{-1}$ (Diaz et al. 2003). Wheat straw processing for ethanol resulted in $\mathrm{pH} 3.6$, COD 150,000 $\mathrm{mg} \mathrm{L}^{-1}$, ammonium $160 \mathrm{mg} \mathrm{L}^{-1}$, and phenols $61 \mathrm{mg} \mathrm{L}^{-1}$ (Kaparaju et al. 2010). 
Table 2. Vinasse Characterization from Some Starch Crops

\begin{tabular}{|c|c|c|c|}
\hline Vinasse type & Parameter & Value & Ref. \\
\hline \multirow{5}{*}{ Rice vinasse } & $\mathrm{pH}$ & $4.8-5.9$ & \multirow{5}{*}{ Yu et al. 2002} \\
\hline & COD & $29,500-35,400$ & \\
\hline & BOD & $15,600-18,700$ & \\
\hline & Total N & $70-140$ & \\
\hline & Total P & $20-30$ & \\
\hline \multirow[t]{10}{*}{ Casssava vinasses } & $\mathrm{pH}$ & $4-5$ & \multirow{4}{*}{ Yang and Li 2013} \\
\hline & COD & $40,000-50,000$ & \\
\hline & $\mathrm{BOD}$ & $20,000-25,000$ & \\
\hline & SS & $25,000-30,000$ & \\
\hline & $\mathrm{pH}$ & $4-4.2$ & \multirow{6}{*}{ (Luo et al. 2009) } \\
\hline & COD & $40,000-70,000$ & \\
\hline & $\mathrm{BOD}$ & $24,000-35,000$ & \\
\hline & SS & $30,000-45,000$ & \\
\hline & Total N & $800-900$ & \\
\hline & Total P & $200-400$ & \\
\hline
\end{tabular}

All values, except $\mathrm{pH}$ are expressed in $\mathrm{mg} \mathrm{L}^{-1}$.

In the fruit wine production, large amounts of water are used in the cleaning and distillation stages (Pap et al. 2004). The vinasses are complex effluents with variable physicochemical properties (Sousa et al. 2019). Table 3 shows high levels of organic compounds, principally polyphenols, as well as other parameters. It has been reported that the phenolic compounds are toxic and can inhibit the bacterial activity (Borja et al. 1993).

Table 3. Physicochemical Properties and Composition of Fruit Vinasses

\begin{tabular}{|c|c|c|c|}
\hline Vinasse type & Parameter & Value & Ref. \\
\hline \multirow{3}{*}{$\begin{array}{l}\text { Mixture of apples } \\
\text { and pears }\end{array}$} & $\mathrm{pH}$ & 3.4 & \multirow{3}{*}{ Robertiello 1982} \\
\hline & BOD & 22,000 & \\
\hline & COD & 48,900 & \\
\hline \multirow{14}{*}{ Grape vinasse } & $\mathrm{pH}$ & 4.71 & \multirow{3}{*}{ Diaz et al. 2002} \\
\hline & Nitrates & 350 & \\
\hline & Ammonium & 50 & \\
\hline & $\mathrm{pH}$ & 4.03 & \multirow{5}{*}{ Díaz-Reinoso et al. 2017} \\
\hline & COD & 70,710 & \\
\hline & Sulfates & 900 & \\
\hline & Total solids & 61,500 & \\
\hline & Phosphates & 1,740 & \\
\hline & $\mathrm{pH}$ & 3.88 & \multirow{6}{*}{ Sousa et al. 2019} \\
\hline & COD & 29,150 & \\
\hline & Ammonium & 218.2 & \\
\hline & Nitrate & 0.01 & \\
\hline & Polyphenols & 1,700 & \\
\hline & Potassium & 2142.0 & \\
\hline
\end{tabular}

All values, except $\mathrm{pH}$ are expressed in $\mathrm{mg} \mathrm{L}^{-1}$. 
Some Agave species are used for liquor production (Ramírez-Malagón et al. 2008). Sotol is obtained from the genus Dasylirion, whereas tequila is produced exclusively from Agave tequilana and mezcal from several species of Agave (Gentry 1982; Pardo-Rueda et al. 2015; CRM 2018). The physicochemical characteristics of tequila and mezcal vinasses are shown in Table 4. Based on this review, mezcal vinasse have more sulfate content than sugarcane vinasse.

Table 4. Tequila and Mezcal Vinasse Characterization

\begin{tabular}{|c|c|c|c|}
\hline Vinasse type & Parameter & Value & Ref. \\
\hline \multirow{9}{*}{ Tequila } & COD & 38,000 & \multirow{4}{*}{ García-Becerra et al. 2019} \\
\hline & $\mathrm{pH}$ & 3.6 & \\
\hline & Acetic acid & 1000 & \\
\hline & Butyric acid & 100 & \\
\hline & BOD & $29,900-30,500$ & \multirow{5}{*}{ Buitrón et al. 2014} \\
\hline & Phenols & $44-81$ & \\
\hline & Sulfates & 915 & \\
\hline & Ammonium & 110 & \\
\hline & $\mathrm{pH}$ & $3.2-4.0$ & \\
\hline \multirow{7}{*}{ Mezcal } & $\mathrm{pH}$ & 3.8 & \multirow{7}{*}{ Cruz-Salomón et al. 2017} \\
\hline & COD & 120,221 & \\
\hline & $\mathrm{BOD}$ & 102,180 & \\
\hline & Total N & 1,600 & \\
\hline & Total P & 723 & \\
\hline & Acetic acid & 15,140 & \\
\hline & Sulfates & 3499.14 & \\
\hline
\end{tabular}

All values, except $\mathrm{pH}$ are expressed in $\mathrm{mg} \mathrm{L}^{-1}$.

All types of biomass can be used as substrates for biogas production (Braun 2007). However the anaerobic digestion of wood is not suitable due to the slow decomposition (Weiland 2010).

The $\mathrm{pH}$ values of all vinasses are very low (Tables 1 to 4 ). So the $\mathrm{pH}$ must be adjusted before starting anaerobic digestion. Weiland (2010) recommended an initial $\mathrm{pH}$ in the digestion systems in the range 7.0 to 8.0.

To avoid process failure by ammonia accumulation, the $\mathrm{C} / \mathrm{N}$ ratio should be between 15 and 30 (Zubr 1986; Weiland 2010), and the macronutrients phosphorus and sulfur are necessary in a ratio of 15:5:1 (Weiland 2010).

Moreover, the inoculum selection as well is used to increase the methane production from vinasse (Ordaz-Díaz and Bailón-Salas 2019). Table 5 shows the methane yield using varied inoculum sources and vinasse types. In methane production from vinasses, different types of inoculum have been used, such as brewery sludge, sludge from a wastewater plant, rumen waste, sludge from poultry slaughterhouse reactor, pulp and paper wastewater, swine wastewater, sludge from distillery waste, and sludge from anaerobic reactor. Based on Table 5, the maximum methane yield was obtained using brewery sludge as the inoculum.

Furthermore regarding the inoculum selection, a mesophilic and constant process is recommended. Fluctuations have been found to affect the biogas production negatively (Levén et al. 2007). 
Table 5. Methane Yield Using Varied Inoculum Source

\begin{tabular}{|c|c|c|c|}
\hline Vinasse type & $\begin{array}{l}\text { Methane yield } \\
\left(\mathrm{L} \mathrm{kg}^{-1} \text { of COD }\right)\end{array}$ & Inoculum source & Reference \\
\hline Tequila & 357 & Brewery & Jáuregui-Jáuregui et al. 2014 \\
\hline Tequila & $240-280$ & Brewery & Arreola-Vargas et al. 2018 \\
\hline Tequila & 290 & Brewery & Arreola-Vargas et al. 2017 \\
\hline Tequila & 290 & Brewery & Toledo-Cervantes et al. 2018 \\
\hline Tequila & 257.9 & Brewery & Buitrón et al. 2014 \\
\hline Mezcal & 307.5 & Wastewater plant & Cruz-Salomón et al. 2017 \\
\hline Sugarcane & 139.17 & Rumen & Syaichurrozi et al. 2013 \\
\hline Sugarcane & 299 & $\begin{array}{l}\text { Granular sludge from } \\
\text { Poultry slaughterhouse } \\
\text { reactor }\end{array}$ & Del Nery et al. 2018 \\
\hline Sugarcane & 246 & $\begin{array}{c}\text { Pulp and } \\
\text { paper wastewater }\end{array}$ & Janke et al. 2015 \\
\hline Sugarcane & 185 & Swine wastewater & de Barros et al. 2016 \\
\hline Sugarcane & $170-240$ & $\begin{array}{l}\text { UASB reactor treating } \\
\text { sugarcane vinasse }\end{array}$ & de Barros et al. 2017 \\
\hline Grape & 340 & - & Petta et al. 2017 \\
\hline $\begin{array}{l}\text { Sorghum, } \\
\text { corn and } \\
\text { wheat } \\
\text { Mixture }\end{array}$ & $214^{a}$ & $\begin{array}{l}\text { Anaerobic reactor fed } \\
\text { with vegetable wastes }\end{array}$ & Ao et al. 2019 \\
\hline $\begin{array}{c}\text { Cane } \\
\text { molasses }\end{array}$ & $6.5-8 \cdot 4^{b}$ & $\begin{array}{l}\text { Sludge from distillery } \\
\text { waste }\end{array}$ & Bories et al. 1988 \\
\hline Cassava & 220 & $\begin{array}{c}\text { Anaerobic granular } \\
\text { sludge from a } \\
\text { mesophilic UASB from } \\
\text { cassava viasse }\end{array}$ & Luo et al. 2009 \\
\hline $\begin{array}{l}\text { Corn whole } \\
\text { stillage } \\
\text { (synthetic) }\end{array}$ & $15.8^{b}$ & $\begin{array}{c}\text { Secondary anaerobic } \\
\text { digested sludge from the } \\
\text { wastewater treatment } \\
\text { plant }\end{array}$ & Andalib et al. 2012 \\
\hline $\begin{array}{l}\text { Corn thin } \\
\text { stillage }\end{array}$ & $1.41^{b}$ & $\begin{array}{c}\text { Sludge from the } \\
\text { mesophilic anaerobic } \\
\text { digester (cattle waste) }\end{array}$ & Lee et al. 2011 \\
\hline Wheat straw & $324^{a}$ & $\begin{array}{l}\text { Sludge from a potato- } \\
\text { processing wastewater } \\
\text { treatment plant }\end{array}$ & Kaparaju et al. 2010 \\
\hline
\end{tabular}

${ }^{\mathrm{a}} \mathrm{k} \mathrm{kg}{ }^{-1} \mathrm{TS},{ }^{\mathrm{b}} \mathrm{m}^{3} \mathrm{~m}^{-3}$ day $^{-1}$. 


\section{BACKGROUND ON ANAEROBIC DIGESTION}

Anaerobic digestion is the fermentation of organic waste in the absence of oxygen (Abbasi et al. 2012). In the anaerobic wastewater treatment, microorganisms carry out the degradation of the organic matter to produce methane, carbon dioxide, and nutrient-rich sludge (Tabatabaei et al. 2010).

\section{Stages and Microorganisms Involved in Methane Production}

The stages of AD are hydrolysis, acidogenesis, acetogenesis, and methanogenesis, where the archaea and bacteria kingdoms participate in the process (Dugba and Zhang 1999).

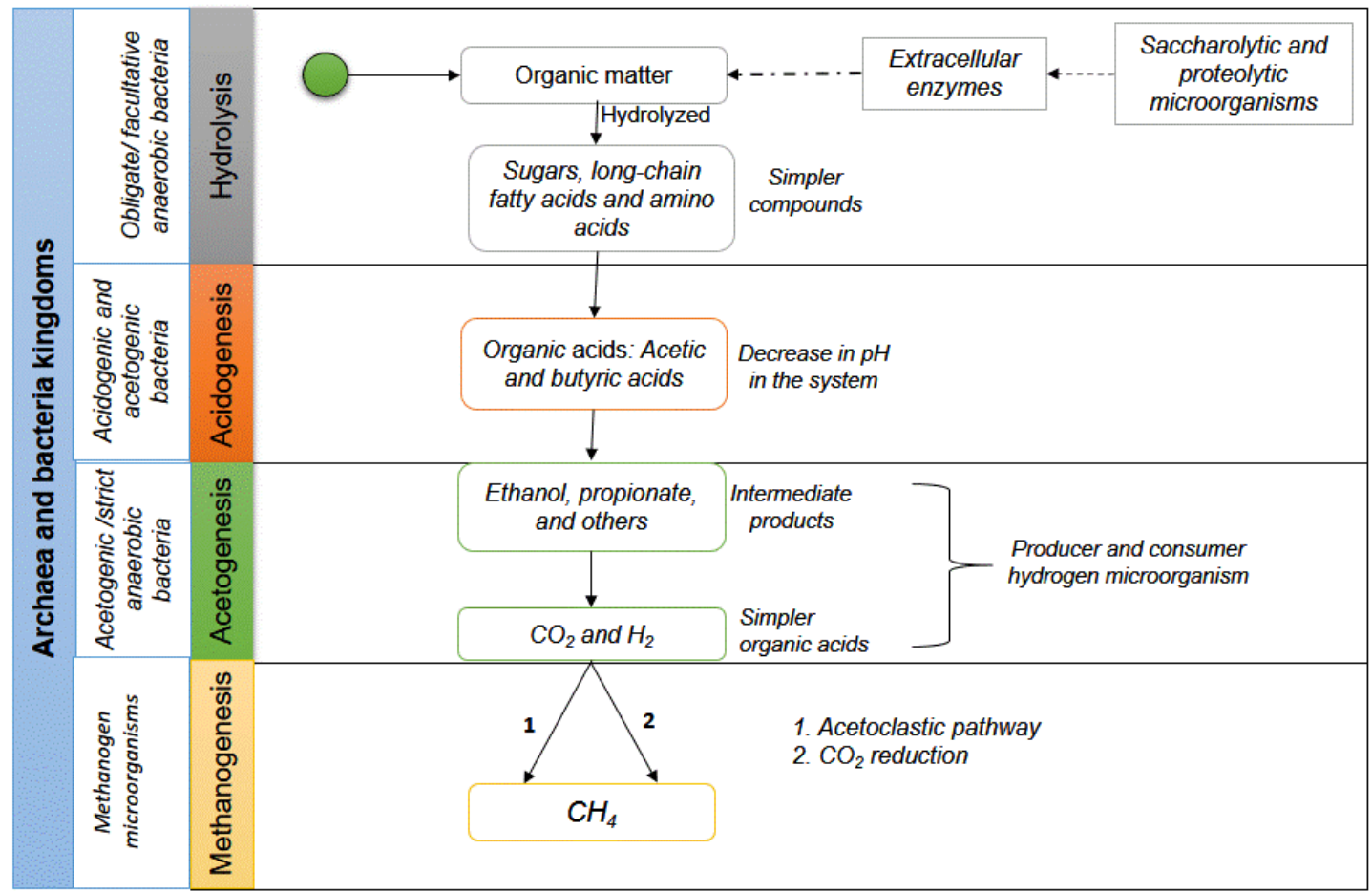

Fig. 1. Flowchart of $A D$ process for the methane production

In the hydrolysis step (Fig. 1), the organic matter (large chains of organic polymers) is hydrolyzed to simpler compounds or monomers by the action of extracellular enzymes produced by hydrolytic bacteria. The saccharolytic and proteolytic microorganisms decompose the sugars and proteins, respectively (Demirel and Scherer 2008). The monomers can be used as a carbon source by other bacteria and by the same hydrolytic bacteria. At this stage, obligate or facultative anaerobic bacteria participate (Vavilin et al. 1996).

Acidogenesis (fermentation) is the quickest reaction, where the hydrolyzed products are further transformed into simpler organic compounds. The sugars, long-chain fatty acids, and amino acids from hydrolysis are used by fermentative microorganisms that produce organic acids (Kalyuzhnyi et al. 2000; Demirel and Scherer 2008). This stage is of great importance, because mainly acetic and butyric acids are precursors for the formation of methane (Hwang et al. 2001). The biotransformation of organic matter to organic acids causes a decrease in $\mathrm{pH}$ in the system. This environment favors acidogenic 
and acetogenic bacteria (Demirel and Yenigün 2002).

In the acetogenesis, strict anaerobic bacteria participate, and these microorganisms grow slowly (Xing et al. 1997). Acetogenic bacteria produce intermediate products such as ethanol, propionate, and others. The intermediate products are converted to simpler organic acids such as $\mathrm{CO}_{2}$ and $\mathrm{H}_{2}$. Microorganisms that produce and consume hydrogen are possible under this condition. The monitoring and reduction of acetogenic microorganisms in addition to the constant elimination of hydrogen are essential to ensure that acetate production is not interrupted or drastically reduced (Demirel and Scherer 2008; Schuchmann and Müller 2016). At this stage, the methane production could be improved by injecting $\mathrm{CO}_{2}$, which produces more acetic acid yield in this stage. This is due to the fact that acetic acid is the direct substrate for methanogenic microorganisms (Li et al. 2019).

Subsequently, methanogen microorganisms consume organic acids and generate biogas. The $\mathrm{CH}_{4}$ is produced by two major pathways: the acetoclastic pathway where approximately two-thirds of the methane is produced, and by $\mathrm{CO}_{2}$ reduction where $\mathrm{CO}_{2}$ reducing methanogens produce the remaining amount of methane. The sulfate content in the vinasse can inhibit methanogenic archaea richness, since the sulfate-reducing bacteria are competing for the carbon sources (Moestedt et al. 2013; Buitrón et al. 2019). Acetotrophic methanogens convert acetate into biomethane and $\mathrm{CO}_{2}$, where $70 \%$ of methane is formed from acetate (Demirbas et al. 2006; Demirel and Scherer 2008). At the end of the process, the biogas produced contains $60 \%$ methane, $40 \%$ carbon dioxide, water vapor, and minimum amounts of hydrogen sulfide (Christy et al. 2014).

As can be seen in Fig. 1, the microorganisms that participate in each stage of methane production are classified at the class level. Microbial consortia composition has been studied for the production of methane from sugarcane vinasse (dos Reis et al. 2015; Dias et al. 2016; de Barros et al. 2017; Iltchenco et al. 2019), brewery vinasse (Enitan et al. 2014), and synthetic vinasse (Rodríguez et al. 2012). These studies just focused on microbial composition identification at initial and/or final times. There has been a lack of available information about other stages that are crucial for methane production. Li et al. (2019) mentioned that the improvement of methane production requires the improvement of each step of anaerobic digestion. Moreover, this cannot be improved if the changes in the microbiota that are responsible for performing a specific function are not known.

\section{Molecular Techniques for the Identification and Monitoring of Microorganisms in the Anaerobic Digestion of Vinasse}

Metagenomics allows the study of microbial communities without the necessity of obtaining pure cultures (Ghosh et al. 2019). Instead, nucleic acids are isolated directly from the sample (Haynes 2008). The basic stages in the study of microbial communities using molecular techniques involves the metagenomic DNA extraction, amplification and sequencing. Other molecular tools are fingerprint methods, such as denaturing gradient gel electrophoresis (DGGE).

The molecular identification of microbial communities is mainly based on the sequence of 16 s ribosomal DNA (rDNA) amplified by the polymerase chain reaction (PCR) (Takami 2019). The V3 and V4 region of the 16s gene has been studied to compare the structures of microbial communities due to the precision in taxonomic assignments (Liu et al. 2007). However, universal single-copy "marker" genes are also ideal candidates for taxonomic analysis of environmental samples (Segata et al. 2012). For example, the rpoB 
gene can be used to calculate relative abundances and provide better bootstrap support for phylogenetic reconstruction (Walsh et al. 2004; Adékambi et al. 2009).

\section{DNA extraction}

Traditional techniques for DNA extraction are based on the use of hazardous chemicals including phenol and chloroform (Griffiths et al. 2000; Nwokeoji et al. 2016) and on the guanidine thiocyanate method (Godon et al. 1997). However, for complex samples of wastewater it has been recommended to use the QIAamp DNA Mini Kit and MO BIO Power Soil DNA Isolation Kit due to the high integrity in terms of diversity (Martínez et al. 2014; Dias et al. 2016; Walden et al. 2017).

\section{Nucleic acid amplification methods}

In studies based on specific genes, amplification is necessary. The PCR allows generating multiple copies of a specific fragment of DNA or RNA (Hoy 2013). The advantage of PCR-based methods is that they are fast and accurate (Tong 2014). However, there are modified methods such as Real-Time PCR (RT-qPCR) or alternative methods based on isothermal amplification.

\section{$R T-q P C R$}

In Real-Time PCR DNA, amplification is detected when the reaction is progressing through a fluorescent reporter, where the intensity of the signal is proportional to the number of amplified DNA molecules (Jia 2012). In the microbial community studies in the $\mathrm{AD}$ of tequila vinasse, the primers W49F / W104R and W274R / W275F were used to amplify the V3 region of the 16S rRNA gene (Jáuregui-Jáuregui et al. 2014; ToledoCervantes et al. 2018).

\section{Isothermal amplification of specific sequences}

In isothermal amplification, specialized equipment is not required, such as a thermocycler. Various proteins help DNA polymerase to replicate the DNA (Gill and Ghaemi 2008). There are several types of isothermal amplification methods such as loopmediated isothermal amplification (LAMP). This amplification method allows for the amplification of six different regions. It is suitable for Sanger and pyrosequencing sequencing (Nagamine et al. 2002; Gill and Ghaemi 2008; Fakruddin and Chowdhury 2012). Other technologies such as strand displacement amplification (SDA), cross priming amplification (CPA), Nicking Enzyme Amplification Reaction (NEAR), and Nicking enzyme-mediated amplification (NEMA) require an additional enzyme, such as a restriction endonuclease or a nicking enzyme. A disadvantage of isothermal amplification of specific sequences is that the components of the reaction mixture and the primer design are more complicated compared to conventional PCR (Tong 2014).

\section{Sequencing and Analysis}

The microbial communities can be identified by high-throughput sequencing, which allows sequencing of the amplicon library for rDNA (Haynes 2008). Other technology includes the single molecule real time (SMRT) that allows for the generation of a full sequence data of 16s rRNA genes. The objective of SMRT is to identify bacterial diversity and community structure at the species level (Yang et al. 2018).

Once the sequence is obtained, they are submitted to a database such as BLAST 
(Altschul et al. 1990), HBLAST (O'Driscoll et al. 2015), or to the Metabolic and Physiological Potential Evaluator (MAPLE) system using the Kyoto Encyclopedia of Genes and Genomes (KEGG) database (Takami 2019). DNA extraction, 16s rDNA amplification, sequencing, and later analysis of the sequences by means of software are required. For example, the Quantitative Insights into Microbial Ecology (QIIME) package allows the analysis of the microbial community based on data from DNA sequences (Navas-Molina et al. 2013).

\section{DNA Fingerprinting Techniques}

Molecular fingerprinting techniques based on the amplification of the 16s rDNA are powerful tools for the study of microbial communities in environmental samples (Kuhn et al. 2017). The PCR-DGGE allows the separation of DNA fragments (same size) previously amplified and the analysis of resulting banding patterns. The double-stranded fragments are separated in polyacrylamide gel with urea-formamide depending on their nucleotide sequence (Myers et al. 1987; Muyzer et al. 1993). In PCR-DGGE, P338f-GC and P518r (Jiménez et al. 2018), 1055F / 1392R-GC (Dias et al. 2016), and 968FGC1401R (Rodríguez et al. 2012; dos Reis et al. 2015) primers have been used for the study of bacterial communities in the AD of vinasse. For the Domain Archaea, Parch519fGC / Arch915r and A109 (T) -F / 515-GC-R primers have been used (Rodríguez et al. 2012; dos Reis et al. 2015). Also, denaturing gradients ranging from $45 \%$ to $60 \%$ (Jiménez et al. 2018) and $30 \%$ to $70 \%$ (Dias et al. 2016) have been used. Other studies have used a gradient of $42 \%$ to $67 \%$ and $30 \%$ to $60 \%$ for bacterial and archaeal communities. The DGGE profiles have been analyzed with the Bionumerics software 5.1 (Applied Maths, Kortrijk, Belgium) (Jiménez et al. 2018), BioNumerics 7.1 (Dias et al. 2016) and BioNumerics 2.5 (dos Reis et al. 2015). The bands obtained are excised, crushed, eluted in milliQ water, re-amplified, purified, and sequenced (Bailón-Salas et al. 2017b). In some studies, bands are not sequenced (Jiménez et al. 2018).

\section{FUNCTIONAL DIVERSITY OF WHOLE MICROBIAL COMMUNITIES}

The objective of metagenomic analysis is to know the function that microbial communities perform in different environments (Takami 2019). However, all the reports of microbial communities related to the production of methane from vinasse and other environments are based on the 16s rDNA gene.

In $\mathrm{AD}$, there has been a limited understanding of the relationship between microbial community structure and function (Venkiteshwaran et al. 2015). To evaluate the metagenomic functionality of microbial communities, Takami et al. (2012, 2014) developed a method. Subsequently Takami et al. (2016) and Arai et al. (2018), respectively, developed and improved a system to evaluate metagenome functionality. The system was called MAPLE, which allows a homology to search much faster than the Basic Local Alignment Search Tool (BLAST) (Takami 2019). In the KEGG module the methane metabolism is available (Takami 2019). 


\section{MICROBIAL COMMUNITIES IDENTIFICATION IN VINASSE REACTORS AND THEIR RELATIONSHIP WITH METHANE PRODUCTION}

Molecular techniques for the microbial identification in reactors for the production of methane from vinasse have been studied in samples of sugarcane vinasse (Martínez et al. 2014; dos Reis et al. 2015; Dias et al. 2016; de Barros et al. 2017; Jiménez et al. 2018), synthetic vinasse (Rodríguez et al. 2012), and tequila vinasse (Jáuregui-Jáuregui et al. 2014; Toledo-Cervantes et al. 2018).

Table 5. Microorganisms Identified in the Production of Methane from Vinasse

\begin{tabular}{|c|c|c|c|}
\hline Microorganism & $\begin{array}{c}\text { Accession } \\
\text { number }\end{array}$ & Source & Reference \\
\hline Uncultured archaeon & JF937237.1 & \multirow{10}{*}{$\begin{array}{c}\text { Fluidized bed reactor } \\
\text { treating synthetic } \\
\text { vinasse at anaerobic } \\
\text { conditions }\end{array}$} & \multirow{10}{*}{$\begin{array}{l}\text { Rodríguez et } \\
\text { al. } 2012\end{array}$} \\
\hline Sporomusa sp. & JF937208.1 & & \\
\hline Acetobacterium sp. & JF937206.1 & & \\
\hline Tissierella sp. & JF937209.1 & & \\
\hline Anaerostipes sp. & JF937202 & & \\
\hline Propionibacterium sp. & JF937214.1 & & \\
\hline Coriobacterium sp. & $\begin{array}{c}\text { JF937213.1, } \\
\text { JF937215.1 and } \\
\text { JF937216.1 }\end{array}$ & & \\
\hline Wolinella sp. & JF937218.1 & & \\
\hline Desulfovibrio sp. & $\begin{array}{c}\text { JF937211.1 and } \\
\text { JF937212.1 }\end{array}$ & & \\
\hline $\begin{array}{c}\text { Uncultured } \\
\text { Halothiobacillaceae } \\
\end{array}$ & JF937210.1 & & \\
\hline Uncultured Prevotella sp. & KM820902.1 & \multirow{5}{*}{$\begin{array}{l}\text { Methane production from } \\
\text { sugarcane vinasse }\end{array}$} & \multirow{5}{*}{$\begin{array}{l}\text { dos Reis et } \\
\text { al. } 2015\end{array}$} \\
\hline Uncultured Clostridia & KM820906.1 & & \\
\hline $\begin{array}{c}\text { Uncultured Megasphaera } \\
\text { sp. }\end{array}$ & KM820904.1 & & \\
\hline Uncultured archaeon & KM820901.1 & & \\
\hline $\begin{array}{c}\text { Uncultured } \\
\text { Methanobacterium sp. }\end{array}$ & KM820898.1 & & \\
\hline Clostridium beijerinckii & KT626859.1 & Vinasse biodigestor & $\begin{array}{c}\text { Database } \\
\text { NCBI, 2015 }\end{array}$ \\
\hline Uncultured Chloroflexi & CU917991.1 & \multirow{7}{*}{$\begin{array}{l}\text { Production of biogas from } \\
\text { sugarcane vinasse }\end{array}$} & \multirow{7}{*}{$\begin{array}{l}\text { Dias et al. } \\
\quad 2016\end{array}$} \\
\hline Desulfomicrobium sp. & JN828421.1 & & \\
\hline Thioalkalimicrobium sp. & GU735085.1 & & \\
\hline Acinetobacter soli & KJ806407.1 & & \\
\hline Thioalkalimicrobium sp. & GU735085.1 & & \\
\hline Pseudomonas sp. & KJ950456.1 & & \\
\hline O. ureolytica & CU927589.1 & & \\
\hline Clostridium beijerinckii & MWMH01000028.1 & $\begin{array}{c}\text { Upflow Anaerobic Sludge } \\
\text { Blanket biodigestor used } \\
\text { to treat sugarcane } \\
\text { vinasse }\end{array}$ & $\begin{array}{l}\text { Database } \\
\text { NCBI, } 2017\end{array}$ \\
\hline
\end{tabular}


Few studies have been conducted with a metagenomic analysis in methane production from vinasses (Rodríguez et al. 2012; Enitan et al. 2014; dos Reis et al. 2015; Dias et al. 2016; de Barros et al. 2017; Iltchenco et al. 2019). In general such approaches are not able to identify microorganisms at the species level, so the specific function in the process is uncertain. Besides, present attempts have not been made to understand the microbial community structure in $\mathrm{AD}$ of mezcal vinasses.

The microorganisms identified in the methane production from vinasse are shown in Table 6. Some references are available in the public database of the NCBI and others was made based in reports of journals.

Sporomusa sp. is strictly an anaerobic bacterium (Möller et al. 1984), isolated from the alcohol distillation industry (Ollivier et al. 1985), and synthetic vinasse (Rodríguez et al. 2012). In the acidogenesis, sugars and fatty acids are converted to organic acids such as acetic, propionic, and butyric acids. In the $\mathrm{AD}$ process, butyrate and propionate are important intermediate compounds (Schink and Stams 2006). It has been reported that some species of the genus Anaerostipes are butyrate producing bacteria (Eeckhaut et al. 2010). Clostridium sp. is a solvent producing bacterium that has the capacity to convert a range of carbohydrates to end products such acetone, butanol, and ethanol. Specifically, Clostridium beijerinckii produces butyric acid and acetic acid (Mitchell 1997; Nimcevic et al. 1998; Little et al. 2015). Some species of Megasphaera have the capability of producing various volatile fatty acids including lactic, formic, acetic, propionic, and butyric acids using sugarcane vinasse (Marx et al. 2011; Sydney et al. 2014). In the raw sugarcane vinasse, high concentrations of propionic acids have been reported as indicating a highly active Propionibacteria community (Júnior et al. 2016). Coriobacterium glomerans has been isolated from the intestinal tract of insects. Glucose, L-arabinose, D-xylose, D-ribose, mannose, sucrose, maltose, cellobiose, mannitol, and salicin are used as a carbon source that are fermented to acetic acid, L-lactic acid, ethanol, $\mathrm{CO}_{2}$, and $\mathrm{H}_{2}$ (Haas and König 1988).

Ethanol and propionate are mainly transformed into simpler organic acids, $\mathrm{CO}_{2}$, and $\mathrm{H}_{2}$ in the acetogenesis step. Acetobacterium sp. converts $\mathrm{H}_{2} / \mathrm{CO}_{2}$ into acetate through acetogenic fermentation (Bainotti and Nishio 2000). Acetobacterium woodii has been the most studied species (Bertsch and Müller 2015; Schuchmann and Müller 2016). At this stage, methylamine is also produced. Tissierella sp. is strictly anaerobic and can produce methylamine (Harms et al. 1998). They were also found to be greatly correlated with the recovered biogas (Chen et al. 2018).

In methanogenesis, the conversion of $\mathrm{CO}_{2}$ and hydrogen to methane is carried out by hydrogenotrophic methanogens (Zabranska and Pokorna 2018). Some genera of Methanobacterium have been associated with this activity (Visser et al. 1991; Harada et al. 1996). The $\mathrm{H}_{2}$ produced in the previous stage must be monitored and eliminated so that the acetate is not reduced. Wolinella succinogenes compete with methanogens microorganisms by consuming $\mathrm{H}_{2}$ (Asanuma et al. 1999). Prevotella sp. utilizes saccharides such as xylan, xylose, pectin, and carboxymethylcellulose, and produces acetate and succinate (Ueki et al. 2007). The acetoclastic microorganism consumes acetate, methanol, and some amines. Pseudomonas sp. can facilitate the extracellular electron transfer and can oxidize various organic electron donors, such as acetate and ethanol (Maruthupandy et al. 2015; Barua et al. 2018).

It has been reported that Thioalkalimicrobium sp. oxizes the sulfur to sulfates (Sorokin et al. 2002). Vinasse obtained from the ethanol distillation has sulfate-rich, liquid 
substrates (Barrera et al. 2013). Methane production can be affected by alternative hydrogen sinks such as sulfates (Johnson and Johnson 1995), where bacteria could remove sulfate in wastewater before anaerobic treatment for biogas production (Promnuan and Sompong 2017). Desulfovibrio sp. removes the dissolved sulfate and produces small amounts of $\mathrm{H}_{2}$ (Martens and Berner 1974; Guyot and Brauman 1986). Desulfomicrobium aspheronum also removes sulfate (Rozanova et al. 1990), and Halothiobacillaceae sp. utilizes reduced sulfur for energy needs (Quek et al. 2017).

\section{CONCLUSIONS}

1. The studies reported in this review focused on microbial composition identification at initial and/or final times. Therefore there is little available information about other stages that are crucial for methane production. Furthermore, there is little information on microbial communities associated with the production of methane from tequila vinasse and null for the mezcal vinasse.

2. Research of microbial communities that participate in the production of biogas from mezcal vinasses is necessary because each microorganism performs a specific function at each stage of the methane production process. In addition, the quality and performance of methane's production process are related to the composition and activity of the microbial community. In each reactor subjected to different conditions, the bacterial diversity that develops in the reactor should be monitored. This information should correlate to maximize methane production, and increase knowledge in this field of research and industry.

3. The molecular tools allow rapid advancement in the knowledge of microbial communities in these habitats. Furthermore, it is time to enrich the functional knowledge of microbial communities, so that cellular metabolism and key functional genes of the microorganisms are better understood.

\section{ACKNOWLEDGMENTS}

The support of the Science and Technology National Council (CONACyT) is gratefully appreciated.

\section{REFERENCES CITED}

Abbasi, T., Tauseef, S.M., and Abbasi, S.A. (2012). Biogas Energy, Springer New York Publisher, New York, NY.

Adékambi, T., Drancourt, M., and Raoult, D. (2009). "The rpoB gene as a tool for clinical microbiologists," Trends in Microbiology 17(1), 37-45. DOI: 10.1016/j.tim.2008.09.008

Aguilar, D. L., Rodríguez-Jasso, R. M., Zanuso, E., de Rodríguez, D. J., AmayaDelgado, L., Sanchez, A., and Ruiz, H. A. (2018). "Scale-up and evaluation of hydrothermal pretreatment in isothermal and non-isothermal regimen for bioethanol 
production using agave bagasse," Bioresource Technology 263, 112-119. DOI: 10.1016/j.biortech.2018.04.100

Altschul, S.F., Gish, W., Miller, W., Myers, E.W., and Lipman, D. J. (1990). "Basic local alignment search tool," Journal of Molecular Biology 215(3), 403-410. DOI: 10.1016/S0022-2836(05)80360-2

Andalib, M., Hafez, H., Elbeshbishy, E., Nakhla, G., and Zhu, J. (2012). "Treatment of thin stillage in a high-rate anaerobic fluidized bed bioreactor (AFBR)," Bioresource technology 121, 411-418. DOI: 10.1016/j.biortech.2012.07.008

Ao, T., Luo, Y., Chen, Y., Cao, Q., Liu, X., and Li, D. (2019). “Towards zero waste: A valorization route of washing separation and liquid hot water consecutive pretreatment to achieve solid vinasse based biorefinery," Journal of Cleaner Production 248, 119253. DOI: 10.1016/j.jclepro.2019.119253

Arai, W., Taniguchi, T., Goto, S., Moriya, Y., Uehara, H., Takemoto, K., Ogata, H., and Takami, H. (2018). "MAPLE 2.3. 0: an improved system for evaluating the functionomes of genomes and metagenomes," Bioscience, Biotechnology, and Biochemistry 82(9), 1515-1517. DOI: 10.1080/09168451.2018.1476122

Arreola-Vargas, J., Jaramillo-Gante, N. E., Celis, L. B., Corona-González, R. I., González-Álvarez, V., and Méndez-Acosta, H. O. (2017). "Biogas production in an anaerobic sequencing batch reactor by using tequila vinasses: Effect of $\mathrm{pH}$ and temperature," Water Science and Technology 73(3), 550-556. DOI:

10.2166/wst.2015.520

Arreola-Vargas, J., Snell-Castro, R., Rojo-Liera, N. M., González-Álvarez, V., and Méndez-Acosta, H. O. (2018). "Effect of the organic loading rate on the performance and microbial populations during the anaerobic treatment of tequila vinasses in a pilot-scale packed bed reactor," Journal of Chemical Technology \& Biotechnology 93(2), 591-599. DOI: 10.1002/jctb.5413

Asanuma, N., Iwamoto, M., and Hino, T. (1999). "Effect of the addition of fumarate on methane production by ruminal microorganisms in vitro," Journal of Dairy Science 82(4), 780-787. DOI: 10.3168/jds.S0022-0302(99)75296-3

Bailón-Salas, A. M., Medrano-Roldán, H., Valle-Cervantes, S., Ordaz-Díaz, L. A., Urtiz-Estrada, N., and Rojas-Contreras, J. A. (2017a). "Review of molecular techniques for the identification of bacterial communities in biological effluent treatment facilities at pulp and paper mills," BioResources 12(2), 4384-4409. DOI: 10.15376/biores.12.2.Bailon_Salas

Bailón-Salas, A. M., Ordaz-Díaz, L. A., Valle-Cervantes, S., López-Miranda, J., UrtizEstrada, N., Páez-Lerma, J. B., de León-Mata, G. D., and Rojas-Contreras, J. A. (2017b). "Bacterial diversity in two aerated lagoons of a pulp and paper effluent and their interaction with a commercial inoculum using PCR-DGGE," BioResources 12(3), 5487-5501. DOI: 10.15376/biores.12.3.5487-5501

Bainotti, A. E., and Nishio, N. (2000). "Growth kinetics of Acetobacterium sp. on methanol-formate in continuous culture," Journal of Applied Microbiology 88(2), 191-201. DOI: 10.1046/j.1365-2672.2000.00854.x

Barrera, E. L., Spanjers, H., Dewulf, J., Romero, O., and Rosa, E. (2013). "The sulfur chain in biogas production from sulfate-rich liquid substrates: A review on dynamic modeling with vinasse as model substrate," Journal of Chemical Technology \& Biotechnology 88(8), 1405-1420. DOI: 10.1002/jctb.4071

Barua, S., Zakaria, B. S., Lin, L., and Dhar, B. R. (2018). "Shaping microbial 
communities with conductive carbon fibers to enhance methane productivity and kinetics," Bioresource Technology Reports 5, 20-27. DOI:

10.1016/j.biteb.2018.11.008

Basu, P. (2010). Biomass Gasification and Pyrolysis: Practical Design and Theory, Academic Press Publisher, Cambridge, MA.

Belhadj, S., Karouach, F., El Bari, H., and Joute, Y. (2013). "The biogas production from mesophilic anaerobic digestion of vinasse," IOSR Journal of Environmental Science, Toxicology and Food Technology 5(6), 72-77. DOI: 10.9790/24020567277

Bertsch, J., and Müller, V. (2015). "CO metabolism in the acetogen Acetobacterium woodii," Applied and Environmental Microbiology 81(17), 5949-5956. DOI: 10.1128/AEM.01772-15

Bories, A., Raynal, J., and Bazile, F. (1988). "Anaerobic digestion of high-strength distillery wastewater (cane molasses stillage) in a fixed-film reactor," Biological Wastes 23(4), 251-267. DOI: 10.1016/0269-7483(88)90014-6

Borja, R., Martin, A., Luque, M., and Duran, M. M. (1993). "Kinetic study of anaerobic digestion of wine distillery wastewater," Process Biochemistry 28(2), 83-90. DOI: 10.1016/0032-9592(93)80011-5

Braun, R. (2007). "Anaerobic digestion: a multi-faceted process for energy, environmental management and rural development," in: Improvement of Crop Plants for Industrial End Uses, Springer, Dordrecht, pp. 335-416. DOI: 10.1007/978-1-4020-5486-0_13

Buitrón, G., Cardeña, R., and Arcila, J. S. (2019). "Bioelectrosynthesis of methane integrated with anaerobic digestion," in: Microbial Electrochemical Technology 2019, Elsevier, Amsterdam, pp. 899-919. DOI: 10.1016/B978-0-444-640529.00037-6

Buitrón, G., Kumar, G., Martinez-Arce, A., and Moreno, G. (2014). "Hydrogen and methane production via a two-stage processes (H2-SBR+CH4-UASB) using tequila vinasses," International Journal of Hydrogen Energy 39(33), 19249-19255. DOI: 10.1016/j.ijhydene.2014.04.139

Chen, S., He, J., Wang, H., Dong, B., Li, N., and Dai, X. (2018). "Microbial responses and metabolic pathways reveal the recovery mechanism of an anaerobic digestion system subjected to progressive inhibition by ammonia," Chemical Engineering Journal 350, 312-323. DOI: 10.1016/j.cej.2018.05.168

Christy, P. M., Gopinath, L. R., and Divya, D. (2014). "A review on anaerobic decomposition and enhancement of biogas production through enzymes and microorganisms," Renewable and Sustainable Energy Reviews 34, 167-173. DOI: 10.1016/j.rser.2014.03.010

Correia, J. E., Christofoletti, C. A., Ansoar-Rodríguez, Y., Guedes, T. A., and Fontanetti, C. S. (2017). "Comet assay and micronucleus tests on Oreochromis niloticus (Perciforme: Cichlidae) exposed to raw sugarcane vinasse and to physicochemical treated vinasse by $\mathrm{pH}$ adjustment with lime $(\mathrm{CaO})$," Chemosphere 173, 494-501. DOI: 10.1016/j.chemosphere.2017.01.025

CRM (2018) Consejo Regulador del Mezcal. Informes http://www.crm.org.mx/periodico/PDF/Revista_El_Mezcal1.pdf Retrieved on January 16, 2018. 
Cruz, R. L., Righetto, A. M., and Nogueira, M. A. (1991). "Experimental investigation of soil and ground water impacts caused by vinasse disposal," Water Science and Technology 24(11), 77-85. DOI: 10.2166/wst.1991.0339

Cruz-Salomón, A., Meza-Gordillo, R., Rosales-Quintero, A., Ventura-Canseco, C., Lagunas-Rivera, S., and Carrasco-Cervantes, J. (2017). "Biogas production from a native beverage vinasse using a modified UASB bioreactor," Fuel 198, 170-174. DOI: 10.1016/j.fuel.2016.11.046

de Barros, V. G. D., Duda, R. M., and Oliveira, R. A. D. (2016). "Biomethane production from vinasse in upflow anaerobic sludge blanket reactors inoculated with granular sludge," Brazilian journal of microbiology 47(3), 628-639. DOI: 10.1016/j.bjm.2016.04.021

de Barros, V. G., Duda, R. M., da Silva Vantini, J., Omori, W. P., Ferro, M. I. T., and de Oliveira, R. A. (2017). "Improved methane production from sugarcane vinasse with filter cake in thermophilic UASB reactors, with predominance of Methanothermobacter and Methanosarcina archaea and Thermotogae bacteria," Bioresource Technology 244, 371-381. DOI: 10.1016/j.biortech.2017.07.106

de Oliveira, B. G., Carvalho, J. L. N., Cerri, C. E. P., Cerri, C. C., and Feigl, B. J. (2013). "Soil greenhouse gas fluxes from vinasse application in Brazilian sugarcane areas," Geoderma 200, 77-84. DOI: 10.1186/s40064-016-2410-3

Del Nery, V., Alves, I., Damianovic, M. H. R. Z., and Pires, E. C. (2018). "Hydraulic and organic rates applied to pilot scale UASB reactor for sugar cane vinasse degradation and biogas generation," Biomass and Bioenergy 119, 411-417. DOI: 10.1016/j.biombioe.2018.10.002

Demirbas, A., Pehlivan, E., and Altun, T. (2006). "Potential evolution of Turkish agricultural residues as bio-gas, bio-char and bio-oil sources," International Journal of Hydrogen Energy 31(5), 613-620. DOI: 10.1016/j.ijhydene.2005.06.003

Demirel, B., and Scherer, P., (2008). "The roles of acetotrophic and hydrogenotrophic methanogens during anaerobic conversion of biomass to methane: A review," Reviews in Environmental Science and Bio/Technology 7, 173-190. DOI: 10.1007/s11157-008-9131-1

Demirel, B., and Yenigün, O. (2002). "Two-phase anaerobic digestion processes: A review," Journal of Chemical Technology \& Biotechnology: International Research in Process 77(7), 743-755. DOI: 10.1002/jctb.630

Dias, M. F., Colturato, L. F., de Oliveira, J. P., Leite, L. R., Oliveira, G., Chernicharo, C. A., and de Araújo, J. C. (2016). "Metagenomic analysis of a desulphurisation system used to treat biogas from vinasse methanisation," Bioresource Technology 205, 58-66. DOI: 10.1016/j.biortech.2016.01.007

Diaz, M. J., Eugenio, M. E., Jimenez, L., Madejon, E., and Cabrera, F. (2003). "Modelling vinasse/cotton waste ratio incubation for optimum composting," Chemical Engineering Journal 93(3), 233-240. DOI: 10.1016/S13858947(02)00252-8

Diaz, M. J., Madejon, E., Lopez, F., Lopez, R., and Cabrera, F. (2002). "Optimization of the rate vinasse/grape marc for co-composting process," Process Biochemistry 37(10), 1143-1150. DOI: 10.1016/S0032-9592(01)00327-2

Díaz-Reinoso, B., Moure, A., González, J., and Domínguez, H. (2017). “A membrane process for the recovery of a concentrated phenolic product from white vinasses," Chemical Engineering Journal 327, 210-217. DOI: 10.1016/j.cej.2017.06.088 
do Carmo, J. B. D., Filoso, S., Zotelli, L. C., de Sousa Neto, E. R., Pitombo, L. M., Duarte-Neto, P. J., Vargas, V. P., Andrade, C. A., Gava, G. J. C., Rossetto, R., Cantarella, H., Neto, A. E., and Martinelli, L. A. (2012). "Infield greenhouse gas emissions from sugarcane soils in Brazil: Effects from synthetic and organic fertilizer application and crop trash accumulation," Gcb Bioenergy 5(3), 267-280. DOI: 10.1111/j.1757-1707.2012.01199.x

dos Reis, C. M., Carosia, M. F., Sakamoto, I. K., Varesche, M. B. A., and Silva, E. L. (2015). "Evaluation of hydrogen and methane production from sugarcane vinasse in an anaerobic fluidized bed reactor," International Journal of Hydrogen Energy 40(27), 8498-8509. DOI: 10.1016/j.ijhydene.2015.04.136

Dugba, P. N., and Zhang, R. (1999). "Treatment of dairy wastewater with two-stage anaerobic sequencing batch reactor systems-thermophilic versus mesophilic operations," Bioresource Technology 68(3), 225-233. DOI: 10.1016/S09608524(98)00156-4

Eeckhaut, V., Van Immerseel, F., Pasmans, F., De Brandt, E., Haesebrouck, F., Ducatelle, R., and Vandamme, P. (2010). "Anaerostipes butyraticus sp. nov., an anaerobic, butyrate-producing bacterium from clostridium cluster XIVa isolated from broiler chicken caecal content, and emended description of the genus Anaerostipes," International Journal of Systematic and Evolutionary Microbiology 60(5), 1108-1112. DOI: 10.1099/ijs.0.015289-0

El-Zaiat, H. M., Ré, D. D., Patino, H. O., and Sallam, S. M. (2019). “Assessment of using dried vinasse rice to replace soybean meal in lambs diets: In vitro, lambs performance and economic evaluation," Small Ruminant Research 173, 1-8. DOI: 10.1016/j.smallrumres.2019.01.003

Enitan, A. M., Kumari, S., Swalaha, F. M., Adeyemo, J., Ramdhani, N., and Bux, F. (2014). "Kinetic modelling and characterization of microbial community present in a full-scale UASB reactor treating brewery effluent," Microbial Ecology 67(2), 358368. DOI: 10.1007/s00248-013-0333-X

España-Gamboa, E., Mijangos-Cortes, J., Barahona-Perez, L., Dominguez-Maldonado, J., Hernández-Zarate, G., and Alzate-Gaviria, L. (2011). "Vinasses: Characterization and treatments," Waste Management \& Research 29(12), 1235-1250. DOI: 10.1177/0734242X10387313

Fakruddin, M. D., and Chowdhury, A. (2012). "Pyrosequencing an alternative to traditional Sanger sequencing," American Journal of Biochemistry and Biotechnology 8(1), 14-20. DOI: 10.3844/ajbbsp.2012.14.20

Fuess, L. T., Zaiat, M., and do Nascimento, C. A. O. (2019). "Novel insights on the versatility of biohydrogen production from sugarcane vinasse via thermophilic dark fermentation: Impacts of $\mathrm{pH}$-driven operating strategies on acidogenesis metabolite profiles," Bioresource Technology 286, 121379. DOI:

10.1016/j.scitotenv.2018.03.326

Fuess, L. T., Garcia, M. L., and Zaiat, M. (2018). "Seasonal characterization of sugarcane vinasse: Assessing environmental impacts from fertirrigation and the bioenergy recovery potential through biodigestion," Science of the Total Environment 634, 29-40. DOI: 10.1016/j.scitotenv.2018.03.326

García, I. G., Venceslada, J. B., Peña, P. J., and Gómez, E. R. (1997). "Biodegradation of phenol compounds in vinasse using Aspergillus terreus and Geotrichum candidum," Water Research 31(8), 2005-2011. DOI: 10.1016/S0043- 


\section{4(97)00014-6}

García-Becerra, M., Macías-Muro, M., Arellano-García, L., and Aguilar-Juárez, O. (2019). "Bio-hydrogen production from tequila vinasses: Effect of detoxification with activated charcoal on dark fermentation performance," International Journal of Hydrogen Energy 44(60), 31860-31872. DOI: 10.1016/j.ijhydene.2019.10.059

Gentry, H. S. (1982). "Agave sisalana," Agaves of Continental North America, University of Arizona Press, Tucson, Arizona, pp. 628-631.

Ghosh, A., Mehta, A., and Khan, A. M. (2019). "Metagenomic analysis and its applications," Encyclopedia of Bioinformatics and Computational Biology 3, 184193. DOI: 10.1016/B978-0-12-809633-8.20178-7

Gill, P., and Ghaemi, A. (2008). "Nucleic acid isothermal amplification technologies A review," Nucleosides, Nucleotides, and Nucleic Acids 27(3), 224-243. DOI: 10.1080/15257770701845204

Godon, J. J., Zumstein, E., Dabert, P., Habouzit, F., and Moletta, R. (1997). "Molecular microbial diversity of an anaerobic digestor as determined by small-subunit rDNA sequence analysis," Applied and Environmental Microbiology 63(7), 2802-2813.

Gouvea, B. M., Torres, C., Franca, A. S., Oliveira, L. S., and Oliveira, E. S. (2009). "Feasibility of ethanol production from coffee husks," Biotechnology Letters 31(9), 1315-1319. DOI: 10.1007/s10529-009-0023-4

Griffiths, R. I., Whiteley, A. S., O'Donnell, A. G., and Bailey, M. J. (2000). 'Rapid method for coextraction of DNA and RNA from natural environments for analysis of ribosomal DNA-and rRNA-based microbial community composition," Applied and Environmental Microbiology 66(12), 5488-5491. DOI:

10.1128/AEM.66.12.5488-5491.2000

Guyot, J. P., and Brauman, A. (1986). "Methane production from formate by syntrophic association of Methanobacterium bryantii and Desulfovibrio vulgaris JJ," Applied and Environmental Microbiology 52(6), 1436-1437.

Haas, F., and König, H. (1988). "Coriobacterium glomerans gen. nov., sp. nov. from the intestinal tract of the red soldier bug," International Journal of Systematic and Evolutionary Microbiology 38(4), 382-384. DOI: 10.1099/00207713-38-4-382

Harada, H., Uemura, S., Chen, A. C., and Jayadevan, J. (1996). "Anaerobic treatment of a recalcitrant distillery wastewater by a thermophilic UASB reactor," Bioresource Technology 55(3), 215-221. DOI: 10.1016/0960-8524(96)00003-X

Harms, C., Schleicher, A., Collins, M. D., and Andreesen, J. R. (1998). "Tissierella creatinophila sp. nov., a gram-positive, anaerobic, non-spore-forming, creatininefermenting organism," International Journal of Systematic and Evolutionary Microbiology 48(3), 983-993. DOI: 10.1099/00207713-48-3-983

Haynes, M. (2008). "Metagenomics," in: Encyclopedia of Ecology, $2^{\text {nd }}$ Ed., Elsevier, Amsterdam, pp. 153-156.

Hoy, M. A. (2013). "DNA amplification by the polymerase chain reaction: Molecular biology made accessible," in: Insect Molecular Genetics, $3^{\text {rd }}$ Ed., M. A. Hoy (ed.), Academic Press, San Diego, CA, pp. 307-372.

Hwang, S., Lee, Y., and Yang, K. (2001). "Maximization of acetic acid production in partial acidogenesis of swine wastewater," Biotechnology and Bioengineering 75(5), 521-529. DOI: 10.1002/bit.10068

Iltchenco, J., Almeida, L. G., Beal, L. L., Marconatto, L., dos Anjos Borges, L. G., Giongo, A., and Paesi, S. (2019). "Microbial consortia composition on the production 
of methane from sugarcane vinasse," Biomass Conversion and Biorefinery 1-11. DOI: $10.1007 / \mathrm{s} 13399-019-00426-0$

Janke, L., Leite, A., Nikolausz, M., Schmidt, T., Liebetrau, J., Nelles, M., and Stinner, W. (2015). "Biogas production from sugarcane waste: Assessment on kinetic challenges for process designing," International Journal of Molecular Sciences 16(9), 20685-20703. DOI: 10.3390/ijms160920685

Jáuregui-Jáuregui, J. A., Méndez-Acosta, H. O., González-Álvarez, V., Snell-Castro, R., Alcaraz-González, V., and Godon, J. J. (2014). "Anaerobic treatment of tequila vinasses under seasonal operating conditions: Start-up, normal operation and restartup after a long stop and starvation period," Bioresource Technology 168, 33-40. DOI: 10.1016/j.biortech.2014.04.006

Jia, Y. (2012). "Real-time PCR," Methods in Cell Biology 112, 55-68. DOI: 10.1016/B978-0-12-405914-6.00003-2

Jiménez, J., Barrera, E. L., De Vrieze, J., Boon, N., DeMeester, S., Spanjers, H., Romero Romero, O., and Dewulf, J. (2018). "Microbial community dynamics reflect reactor stability during the anaerobic digestion of a very high strength and sulfate-rich vinasse," Journal of Chemical Technology \& Biotechnology 93(4), 975984. DOI: $10.1002 /$ jctb.5449

Johnson, K. A, and Johnson, D. E. (1995). "Methane emissions from cattle," Journal of Animal Science 73(8), 2483-2492. DOI: 10.2527/1995.7382483x

Joppert, C. L., dos Santos, M. M., Costa, H. K., dos Santos, E. M., and Moreira, J. R. S. (2017). "Energetic shift of sugarcane bagasse using biogas produced from sugarcane vinasse in Brazilian ethanol plants," Biomass and bioenergy 107, 63-73. DOI: 10.1016/j.biombioe.2017.09.011

Júnior, A. D. N. F., Koyama, M. H., de Araújo Júnior, M. M., and Zaiat, M. (2016). "Thermophilic anaerobic digestion of raw sugarcane vinasse," Renewable Energy 89, 245-252. DOI: 10.1016/j.renene.2015.11.064

Kalyuzhnyi, S., Veeken, A., and Hamelers, B. (2000). "Two-particle model of anaerobic solid state fermentation," Water Science and Technology 41(3), 43-50. DOI: $10.2166 /$ wst.2000.0054

Kaparaju, P., Serrano, M., and Angelidaki, I. (2010). "Optimization of biogas production from wheat straw stillage in UASB reactor," Applied Energy 87(12), 3779-3783. DOI: 10.1016/j.apenergy.2010.06.005

Kuhn, R., Böllmann, J., Krahl, K., Bryant, I. M., and Martienssen, M. (2017). "Comparison of ten different DNA extraction procedures with respect to their suitability for environmental samples," Journal of Microbiological Methods 143, 78-86. DOI: 10.1016/j.mimet.2017.10.007

Lee, P. H., Bae, J., Kim, J., and Chen, W. H. (2011). "Mesophilic anaerobic digestion of corn thin stillage: A technical and energetic assessment of the corn-to-ethanol industry integrated with anaerobic digestion," Journal of Chemical Technology \& Biotechnology 86(12), 1514-1520. DOI: 10.1002/jctb.2664

Leme, R. M., and Seabra, J. E. (2017). "Technical-economic assessment of different biogas upgrading routes from vinasse anaerobic digestion in the Brazilian bioethanol industry," Energy 119, 754-766. DOI: 10.1016/j.energy.2016.11.029

Levén, L., Eriksson, A. R., and Schnürer, A. (2007). "Effect of process temperature on bacterial and archaeal communities in two methanogenic bioreactors treating organic household waste," FEMS Microbiology Ecology 59(3), 683-693. DOI: 
10.1111/j.1574-6941.2006.00263.x

Li, Y., Chen, Y., and Wu, J. (2019). "Enhancement of methane production in anaerobic digestion process: A review," Applied energy 240, 120-137. DOI: 10.1016/j.apenergy.2019.01.243

Lin, Y., and Tanaka, S. (2006). "Ethanol fermentation from biomass resources: Current state and prospects," Applied Microbiology and Biotechnology 69(6), 627-642. DOI: 10.1007/s00253-005-0229-x

Little, G. T., Winzer, K., and Minton, N. P. (2015). "Genome sequence of the solventproducing Clostridium beijerinckii strain 59B, isolated from Staffordshire garden soil," Genome Announcements 3(2), e00108-15. DOI: 10.1128/genomeA.00108-15

Liu, Y., Xu, J., Zhang, Y., Yuan, Z., He, M., Liang, C., Zhuang, X., and Xie, J. (2015). "Sequential bioethanol and biogas production from sugarcane bagasse based on high solids fed-batch SSF," Energy 90, 1199-1205. DOI:10.1016/j.energy.2015.06.066

Liu, Z., Lozupone, C., Hamady, M., Bushman, F. D., and Knight, R. (2007). "Short pyrosequencing reads suffice for accurate microbial community analysis," Nucleic Acids Research 35(18), e120. DOI: 10.1093/nar/gkm541

Lu, Y., Lai, Q., Zhang, C., Zhao, H., Ma, K., Zhao, X., Chen, H., Liu, D., and Xing, X. H. (2009). "Characteristics of hydrogen and methane production from cornstalks by an augmented two-or three-stage anaerobic fermentation process," Bioresource Technology 100(12), 2889-2895. DOI: 10.1016/j.biortech.2009.01.023

Lu-Chau, T. A., García-Torreiro, M., López-Abelairas, M., Gómez-Vanegas, N. A., Gullón, B., Lema, J. M., and Eibes, G. (2019). "Application of fungal pretreatment in the production of ethanol from crop residues," in: Bioethanol Production from Food Crops Academic Press, Cambridge, MA, pp. 267-292. DOI: 10.1016/B978-012-813766-6.00014-X

Luo, G., Xie, L., and Zhou, Q. (2009). "Enhanced treatment efficiency of an anaerobic sequencing batch reactor (ASBR) for cassava stillage with high solids content," Journal of Bioscience and Bioengineering 107(6), 641-645. DOI: 10.1016/j.jbiosc.2009.01.015

Martens, C. S., and Berner, R. A. (1974). "Methane production in the interstitial waters of sulfate-depleted marine sediments," Science 185(4157), 1167-1169. DOI: 10.1126/science.185.4157.1167

Martínez, M. A., Romero, H., and Perotti, N. I. (2014). “Two amplicon sequencing strategies revealed different facets of the prokaryotic community associated with the anaerobic treatment of vinasses from ethanol distilleries," Bioresource Technology 153, 388-392. DOI: 10.1016/j.biortech.2013.12.030

Marty, D., Bonin, P., Michotey, V., and Bianchi, M. (2001). "Bacterial biogas production in coastal systems affected by freshwater inputs," Continental Shelf Research 21(18-19), 2105-2115. DOI: 10.1016/S0278-4343(01)00045-0

Maruthupandy, M., Anand, M., Maduraiveeran, G., Beevi, A. S. H., and Priya, R. J. (2015). "Electrical conductivity measurements of bacterial nanowires from Pseudomonas aeruginosa," Advances in Natural Sciences: Nanoscience and Nanotechnology 6(4), 045007. DOI: 10.1088/2043-6262/6/4/045007

Marx, H., Graf, A. B., Tatto, N. E., Thallinger, G. G., Mattanovich, D., and Sauer, M. (2011). "Genome sequence of the ruminal bacterium Megasphaera elsdenii," Journal of Bacteriology 193(19), 5578-5579. DOI: 10.1128/JB.05861-11

Mitchell, W. J. (1997). "Physiology of carbohydrate to solvent conversion by 
clostridia," Advances in Microbial Physiology 39, 31-130. DOI: 10.1016/S00652911(08)60015-6

Moestedt, J., Påledal, S. N., and Schnürer, A. (2013). "The effect of substrate and operational parameters on the abundance of sulphate-reducing bacteria in industrial anaerobic biogas digesters," Bioresource Technology 132, 327-332. DOI: 10.1016/j.biortech.2013.01.043

Moletta, R. (2005). "Winery and distillery wastewater treatment by anaerobic digestion," Water Science and Technology 51(1), 137-144. DOI: 10.2166/wst.2005.0017

Möller, B., Oßmer, R., Howard, B. H., Gottschalk, G., and Hippe, H. (1984). "Sporomusa, a new genus of gram-negative anaerobic bacteria including Sporomusa sphaeroides spec. nov. and Sporomusa ovata spec. nov," Archives of Microbiology 139(4), 388-396. DOI: 10.1007/BF00408385

Moraes, B. S., Petersen, S. O., Zaiat, M., Sommer, S. G., and Triolo, J. M. (2017). "Reduction in greenhouse gas emissions from vinasse through anaerobic digestion," Applied Energy 189, 21-30. DOI: 10.1016/j.apenergy.2016.12.009

Moraes, B. S., Zaiat, M., and Bonomi, A. (2015). "Anaerobic digestion of vinasse from sugarcane ethanol production in Brazil: Challenges and perspectives," Renewable \& Sustainable Energy Reviews 44, 888-903. DOI: 10.1016/j.rser.2015.01.023

Moran-Salazar, R. G., Sanchez-Lizarraga, A. L., Rodriguez-Campos, J., DavilaVazquez, G., Marino-Marmolejo, E. N., Dendooven, L., and Contreras-Ramos, S. M. (2016). "Utilization of vinasses as soil amendment: Consequences and perspectives," Springerplus 5(1), 1007. DOI: 10.1186/s40064-016-2410-3

Muyzer, G., De Waal, E. C., and Uitterlinden, A. G. (1993). "Profiling of complex microbial populations by denaturing gradient gel electrophoresis analysis of polymerase chain reaction-amplified genes coding for 16S rRNA," Applied and Environmental Microbiology 59(3), 695-700.

Myers, R. M., Maniatis, T., and Lerman, L. S. (1987). "Detection and localization of single base changes by denaturing gradient gel electrophoresis," Methods in Enzymology 155, 501-527. DOI: 10.1016/0076-6879(87)55033-9

Nagamine, K., Kuzihara, Y., and Notomi, T. (2002). "Isolation of single-stranded DNA from loopmediated isothermal amplification products," Biochemical and Biophysical Research Communications 290(4), 1195-1198. DOI: 10.1006/bbrc.2001.6334

Navas-Molina, J. A., Peralta-Sánchez, J. M., González, A., McMurdie, P. J., VázquezBaeza, Y., Xu, Z., Ursell, L. K., Lauber, C., Zhou, H., Song, S. J., et al. (2013). "Advancing our understanding of the human microbiome using QIIME," Methods in Enzymology 531, 371-444. DOI: 10.1016/B978-0-12-407863-5.00019-8

Nimcevic, D., Schuster, M., and Gapes, J. R. (1998). "Solvent production by Clostridium beijerinckii NRRL B592 growing on different potato media," Applied Microbiology and Biotechnology 50(4), 426-428. DOI: 10.1007/s002530051315

Nwokeoji, A. O., Kilby, P. M., Portwood, D. E., and Dickman, M. J. (2016). "RNASwift: A rapid, versatile RNA extraction method free from phenol and chloroform," Analytical Biochemistry 512, 36-46. DOI: 10.1016/j.ab.2016.08.001

O’Driscoll, A., Belogrudov, V., Carroll, J., Kropp, K., Walsh, P., Ghazal, P., and Sleator, R. D. (2015). "HBLAST: Parallelised sequence similarity-A Hadoop MapReducable basic local alignment search tool," Journal of Biomedical 
Informatics 54, 58-64. DOI: 10.1016/j.jbi.2015.01.008

Ollivier, B., Cordruwisch, R., Lombardo, A., and Garcia, J. L. (1985). "Isolation and characterization of Sporomusa acidovorans sp. nov., a methylotrophic homoacetogenic bacterium," Archives of Microbiology 142(3), 307-310. DOI: 10.1007/BF00693409

Ordaz-Díaz, L. A., and Bailón-Salas, A. M. (2019). "Bioreactors employed for methane production from vinasse: A review," in: Colaboraciones de Cuerpos Académicos en Innovación Tecnológica. Red Iberoamericana de Academias de Investigación A.C., Veracruz, México, pp. 223-233.

Pap, N., Pongrácz, E., Myllykoski, L., and Keiski, R. (2004). "Waste minimization and utilization in the food industry: Processing of arctic berries, and extraction of valuable compounds from juice-processing by-products," in: Proceedings of the Waste Minimization and Resources Use Optimization Conference 10,159-168. Oulu: Oulu University Press.

Pardo-Rueda, A. J., Quintero-Ramos, A., Genovese, D. B., Camacho-Dávila, A., Zepeda-Rodríguez, A., Contreras-Esquivel, J. C., and Bizarro, A. P. (2015). "Efficient extraction of fructans from sotol plant (Dasylirion leiophyllum) enhanced by a combination of enzymatic and sonothermal treatments," Food and Bioproducts Processing 94, 398-404. DOI: 10.1016/j.fbp.2014.05.005

Parsaee, M., Kiani, M. K. D., and Karimi, K. (2019). "A review of biogas production from sugarcane vinasse," Biomass and bioenergy 122, 117-125. DOI:

10.1016/j.biombioe.2019.01.034

Petta, L., De Gisi, S., Casella, P., Farina, R., and Notarnicola, M. (2017). "Evaluation of the treatability of a winery distillery (vinasse) wastewater by UASB, anoxicaerobic UF-MBR and chemical precipitation/adsorption," Journal of environmental management 201, 177-189. DOI: 10.1016/j.jenvman.2017.06.042

Promnuan, K., and Sompong, O. (2017). "Biological hydrogen sulfide and sulfate removal from rubber smoked sheet wastewater for enhanced biogas production," Energy Procedia 138, 569-574. DOI: 10.1016/j.egypro.2017.10.161

Quek, P. J., Yeap, T. S., and Ng, H. Y. (2017). "Applicability of upflow anaerobic sludge blanket and dynamic membrane-coupled process for the treatment of municipal wastewater," Applied Microbiology and Biotechnology 101(16), 65316540. DOI: 10.1007/s00253-017-8358-6

Ramírez-Malagón, R., Borodanenko, A., Pérez-Moreno, L., Salas-Araiza, M. D., Nunez-Palenius, H. G., and Ochoa-Alejo, N. (2008). "In vitro propagation of three Agave species used for liquor distillation and three for landscape," Plant Cell, Tissue and Organ Culture 94(2), 201-207. DOI: 10.1007/s11240-008-9405-x

Robertiello, A. (1982). "Upgrading of agricultural and agro-industrial wastes: The treatment of distillery effluents (vinasses) in Italy," Agricultural Wastes 4(5), 387395. DOI: 10.1016/0141-4607(82)90033-6

Robles-González, V., Galíndez-Mayer, J., Rinderknecht-Seijas, N., and Poggi-Varaldo, H. M. (2012). "Treatment of mezcal vinasses: A review," Journal of Biotechnology 157(4), 524-546. DOI: 10.1016/j.jbiotec.2011.09.006

Rodríguez, E., Lopes, A., Polanco, M. F., Stams, A. J., and García-Encina, P. A. (2012). "Molecular analysis of the biomass of a fluidized bed reactor treating synthetic vinasse at anaerobic and micro-aerobic conditions," Applied Microbiology and Biotechnology 93(5), 2181-2191. DOI: 10.1007/s00253-011-3529-3 
Rozanova, E., Galushko, A., and Nazina, T. (1990). "An acetate-decomposing sulphidogenic syntrophic association," in: Microbiology and Biochemistry of Strict Anaerobes Involved in Interspecies Hydrogen Transfer Springer, Boston, MA, pp. 469-470. DOI: 10.1007/978-1-4613-0613-9_62

Santos, P. S., Zaiat, M., do Nascimento, C. A. O., and Fuess, L. T. (2019). 'Does sugarcane vinasse composition variability affect the bioenergy yield in anaerobic systems? A dual kinetic-energetic assessment," Journal of Cleaner Production 240, 118005. DOI: 10.1016/j.jclepro.2019.118005

Saunois, M., Bousquet, P., Poulter, B., Peregon, A., Ciais, P., Canadell, J. G., Dlugokencky, E. J., Etiope, G., Bastviken, D., Houweling, S., et al. (2016). "The global methane budget 2000-2012," Earth System Science Data 8(2), 697-751. DOI: 10.5194/essd-8-697-2016

Schink, B., and Stams, A. J. M. (2006). "Syntrophism among prokaryotes," in: The Prokaryotes, M. Dworkin, K.-H. Schleifer, and E. Stackebrandt (eds.), Springer Verlag, Berlin, pp. 309-335.

Schuchmann, K., and Müller, V. (2016). "Energetics and application of heterotrophy in acetogenic bacteria," Applied and Environmental Microbiology 82(14), 4056-4069. DOI: 10.1128/AEM.00882-16

Segata, N., Waldron, L., Ballarini, A., Narasimhan, V., Jousson, O., and Huttenhower, C. (2012). "Metagenomic microbial community profiling using unique cladespecific marker genes," Nature Methods 9(8), 811. DOI: 10.1038/nmeth.2066

Sorokin, D. Y., Gorlenko, V. M., Tat'yana, P. T., Tsapin, A. I., Nealson, K. H., and Kuenen, G. J. (2002). “Thioalkalimicrobium cyclicum sp. nov. and Thioalkalivibrio jannaschii sp. nov., novel species of haloalkaliphilic, obligately chemolithoautotrophic sulfur-oxidizing bacteria from hypersaline alkaline Mono Lake (California)," International Journal of Systematic and Evolutionary Microbiology 52(3), 913-920. DOI: 10.1099/00207713-52-3-913

Sousa, R. M. O., Amaral, C., Fernandes, J. M., Fraga, I., Semitela, S., Braga, F., Coimbra, A. M., Dias, A. A., Bezerra, R. M., and Sampaio, A. (2019). "Hazardous impact of vinasse from distilled winemaking by-products in terrestrial plants and aquatic organisms," Ecotoxicology and Environmental Safety 183, 109493. DOI: 10.1016/j.ecoenv.2019.109493

Syaichurrozi, I., Budiyono, and Sumardiono, S. (2013). "Predicting kinetic model of biogas production and biodegradability organic materials: Biogas production from vinasse at variation of COD/N ratio," Bioresource Technology 149, 390-397. DOI: 10.1016/j.biortech.2013.09.088

Sydney, E. B., Larroche, C., Novak, A. C., Nouaille, R., Sarma, S. J., Brar, S. K., Letti, L. A, Soccol, V. T., and Soccol, C. R. (2014). "Economic process to produce biohydrogen and volatile fatty acids by a mixed culture using vinasse from sugarcane ethanol industry as nutrient source," Bioresource Technology 159, 380386. DOI: 10.1016/j.biortech.2014.02.042

Tabatabaei, M., Rahim, R. A., Abdullah, N., Wright, A. D. G., Shirai, Y., Sakai, K., Sulaiman, A., and Hassan, M. A. (2010). "Importance of the methanogenic archaea populations in anaerobic wastewater treatments," Process Biochemistry 45(8), 12141225. DOI: $10.1016 /$ j.procbio.2010.05.017

Takami, H. (2014). "New method for comparative functional genomics and metagenomics using KEGG module," in: Encyclopedia of Metagenomics: Genes, 
Genomes and Metagenomes: Basics, Methods, Databases and Tools Springer, New York, pp. 525-539. DOI: 10.1007/978-1-4899-7478-5

Takami, H. (2019). "Molecular tools in microbial diversity: Functional assessment tool for genomes and metagenomes, MAPLE system," in: Microbial Diversity in the Genomic Era, Academic Press, Cambridge, MA, pp. 117-136. DOI: 10.1016/B9780-12-814849-5.00008-3

Takami, H., Taniguchi, T., Arai, W., Takemoto, K., Moriya, Y., and Goto, S. (2016). "An automated system for evaluation of the potential functionome: MAPLE version 2.1. 0," DNA Research 23(5), 467-475. DOI: 10.1093/dnares/dsw030

Takami, H., Taniguchi, T., Moriya, Y., Kuwahara, T., Kanehisa, M., and Goto, S. (2012). "Evaluation method for the potential functionome harbored in the genome and metagenome," BMC Genomics 13(699), 1-15. DOI: 10.1186/1471-2164-13-699

Tian, Z., Mohan, G. R., Ingram, L., and Pullammanappallil, P. (2013). "Anaerobic digestion for treatment of stillage from cellulosic bioethanol production," Bioresource technology 144, 387-395. DOI: 10.1016/j.biortech.2013.06.119

Toledo-Cervantes, A., Guevara-Santos, N., Arreola-Vargas, J., Snell-Castro, R., and Méndez-Acosta, H. O. (2018). "Performance and microbial dynamics in packed-bed reactors during the long-term two-stage anaerobic treatment of tequila vinasses," Biochemical Engineering Journal 138, 12-20. DOI: 10.1016/j.bej.2018.06.020

Tong, Y. (2014). "Isothermal amplification of specific sequences," in: Biological Identification, R. P. Schaudies (ed.), Woodhead Publishing, Waltham, MA, pp. 6992.

Ueki, A., Akasaka, H., Satoh, A., Suzuki, D., and Ueki, K. (2007). "Prevotella paludivivens sp. nov., a novel strictly anaerobic, Gram-negative, hemicellulosedecomposing bacterium isolated from plant residue and rice roots in irrigated ricefield soil," International Journal of Systematic and Evolutionary Microbiology 57(8), 1803-1809. DOI: 10.1099/ijs.0.64914-0

Vavilin, V. A., Rytov, S. V., and Lokshina, L. Y. (1996). "A description of hydrolysis kinetics in anaerobic degradation of particulate organic matter," Bioresource Technology 56(2-3), 229-237. DOI: 10.1016/0960-8524(96)00034-X

Venkiteshwaran, K., Bocher, B., Maki, J., and Zitomer, D. (2015). "Relating anaerobic digestion microbial community and process function," Microbiology Insights 8, MBI-S33593, Supplementary issue: Water microbiology, pp. 37-44. DOI: 10.4137/MBI.S33593

Visser, F. A., van Lier, J. B., Macario, A. J., and de Macario, E. C. (1991). "Diversity and population dynamics of methanogenic bacteria in a granular consortium," Applied and Environmental Microbiology 57(6), 1728-1734.

Volpini, V., Lovato, G., Albanez, R., Ratusznei, S. M., and Rodrigues, J. A. D. (2018). "Biomethane generation in an AnSBBR treating effluent from the biohydrogen production from vinasse: Optimization, metabolic pathways modeling and scale-up estimation," Renewable Energy 116, 288-298. DOI: 10.1016 / j.renene.2017.09.004

Walden, C., Carbonero, F., and Zhang, W. (2017). "Assessing impacts of DNA extraction methods on next generation sequencing of water and wastewater samples," Journal of Microbiological Methods 141, 10-16. DOI: 10.1016/j.mimet.2017.07.007

Walsh, D. A., Bapteste, E., Kamekura, M., and Doolittle, W. F. (2004). "Evolution of the RNA polymerase $\mathrm{B}^{\prime}$ subunit gene ( $\mathrm{rpoB}^{\prime}$ ) in Halobacteriales: A complementary 
molecular marker to the SSU rRNA gene," Molecular Biology and Evolution 21(12), 2340-2351. DOI: 10.1093/molbev/msh248

Wang, E. Q., Li, S. Z., Tao, L., Geng, X., and Li, T. C. (2010). "Modeling of rotating drum bioreactor for anaerobic solid-state fermentation," Applied Energy 87(9), 2839-2845. DOI: 10.1016/j.apenergy.2009.05.032

Weiland, P. (2010). "Biogas production: Current state and perspectives," Applied Microbiology and Biotechnology 85(4), 849-860. DOI: 10.1007/s00253-009-2246-7

Wu, F. C., Huang, S. S., and Shih, L. (2014). "Sequential hydrolysis of waste newspaper and bioethanol production from the hydrolysate," Bioresource Technology 167, 159-168. DOI: 10.1016/j.biortech.2014.06.041

Xing, J., Criddle, C., and Hickey, R. (1997). "Effects of a long-term periodic substrate perturbation on an anaerobic community," Water Research 31(9), 2195-2204. DOI: 10.1016/S0043-1354(97)00064-X

Yang, H., and Li, S. (2013). "Energy analysis of cassava vinasse treatment," Process Safety and Environmental Protection 91(6), 503-507. DOI: 10.1016/j.psep.2013.01.003

Yang, J., Cao, J., Xu, H., Hou, Q., Yu, Z., Zhang, H., and Sun, Z. (2018). 'Bacterial diversity and community structure in Chongqing radish paocai brines revealed using PacBio single-molecule real-time sequencing technology," Journal of the Science of Food and A griculture 98(9), 3234-3245 DOI: 10.1002/jsfa.8935

$\mathrm{Yu}, \mathrm{H}$. , Zhu, Z., Hu, W., and Zhang, H. (2002). "Hydrogen production from rice winery wastewater in an upflow anaerobic reactor by using mixed anaerobic cultures," International Journal of Hydrogen Energy 27(11-12), 1359-1365. DOI: 10.1016/S0360-3199(02)00073-3

Zabranska, J., and Pokorna, D. (2018). "Bioconversion of carbon dioxide to methane using hydrogen and hydrogenotrophic methanogens," Biotechnology Advances 35(3), 707-720. DOI: 10.1016/j.biotechadv.2017.12.003

Zhang, M., Xie, L., Yin, Z., Khanal, S. K., and Zhou, Q. (2016). "Biorefinery approach for cassava-based industrial wastes: current status and opportunities," Bioresource Technology 215, 50-62. DOI: 10.1016/j.biortech.2016.04.026

Zubr, J. (1986). "Methanogenic fermentation of fresh and ensiled plant materials," Biomass 11(3), 159-171. DOI: 10.1016/0144-4565(86)90064-8

Article submitted: October 4, 2019; Peer review completed: January 23, 2020; Revised version received and accepted: February 16, 2020; Published: February 25, 2020.

DOI: 10.15376/biores.15.2.Diaz 